\title{
Antioxidant Capacity of Macaronesian Traditional Medicinal Plants
}

\author{
Lucélia Tavares ${ }^{1}$, Dina Carrilho ${ }^{1}$, Meenu Tyagi ${ }^{1}$, David Barata ${ }^{1}$, Ana Teresa Serra ${ }^{2}$, \\ Catarina Maria Martins Duarte ${ }^{2}$, Rui Oliveira Duarte ${ }^{3}$, Rodrigo Pedro Feliciano ${ }^{4}$, \\ Maria Rosário Bronze ${ }^{4,5}$, Paula Chicau ${ }^{6}$, Maria Dalila Espírito-Santo ${ }^{7}$, \\ Ricardo Boavida Ferreira ${ }^{1,7}$ and Cláudia Nunes dos Santos ${ }^{1, *}$
}

1 Disease \& Stress Biology, Instituto de Tecnologia Química e Biológica, Universidade Nova de Lisboa, 2781-901 Oeiras, Portugal; E-Mails: 1tavares@itqb.unl.pt(L.T.); carrilho@itqb.unl.pt(D.C.); tyagi@itqb.unl.pt(M.T.); dbarata@gmail.com(D.B.); rbferreira@itqb.unl.pt(R.B.F.)

2 Nutraceuticals and Delivery Laboratory, Instituto de Tecnologia Química e Biológica/ IBET, Universidade Nova de Lisboa, 2781-901 Oeiras, Portugal;

E-Mails: tserra@itqb.unl.pt(A.T.S.); cduarte@itqb.unl.pt(C.M.M.D.)

3 REQUIMTE, Faculdade de Ciências e Tecnologia, Universidade Nova de Lisboa, 2829-516 Caparica, Portugal; E-Mail: rod@dq.fct.unl.pt(R.O.D.)

4 Analytical Chemistry Laboratory, Instituto de Tecnologia Química e Biológica, Universidade Nova de Lisboa, 2781-901 Oeiras, Portugal; E-Mails: rodrigof@itqb.unl.pt(R.F.); mbronze@itqb.unl.pt(M.R.B.)

5 Faculdade de Farmácia da Universidade de Lisboa, Av. Prof. Gama Pinto,1649-003 Lisboa, Portugal; E-Mail: mrbronze@ff.ul.pt(M.R.B.)

6 Analytical Laboratory, Instituto de Tecnologia Química e Biológica, Universidade Nova de Lisboa, 2781-901 Oeiras, Portugal; E-Mail: chicau@itqb.unl.pt(P.C)

7 Instituto Superior de Agronomia, Centro de Botânica Aplicada à Agricultura, Universidade Técnica de Lisboa, Tapada da Ajuda, 1349-017 Lisboa, Portugal; E-Mails: dalilaesanto@isa.utl.pt(M.D.E.); rbferreira@isa.utl.pt(R.B.F.)

* Author to whom correspondence should be addressed; E-Mail: csantos@itqb.unl.pt; Tel.: +351214469651; Fax: +351214433644.

Received: 9 February 2010; in revised form: 30 March 2010 / Accepted: 6 April 2010 / Published: 12 April 2010

Abstract: The use of many traditional medicinal plants is often hampered by the absence of a proper biochemical characterization, essential to identify the bioactive compounds 
present. The leaves from five species endemic to the Macaronesian islands with recognized ethnobotanical applications were analysed: Apollonias barbujana (Cav.) Bornm., Ocotea foetens (Ainton) Baill, Prunus azorica (Mouill.) Rivas-Mart., Lousã, Fern. Prieto, E. Días, J.C. Costa \& C. Aguiar, Rumex maderensis Lowe and Plantago arborescens Poir. subsp. maderensis (Dcne.) A. Hans. et Kunk.. Since oxidative stress is a common feature of most diseases traditionally treated by these plants, it is important to assess their antioxidant capacity and determine the molecules responsible for this capacity. In this study, the antioxidant capacity of these plants against two of the most important reactive species in human body (hydroxyl and peroxyl radicals) was determined. To trace the antioxidant origin total phenol and flavonoid contents as well as the polyphenolic profile and the amount of trace elements were determined. There was a wide variation among the species analysed in what concerns their total leaf phenol and flavonoid contents. From the High Performance Liquid Chromatography (HPLC) electrochemically detected peaks it was possible to attribute to flavonoids the antioxidant capacity detected in A. barbujana, $O$. foetens, $R$. maderensis and $P$. azorica extracts. These potential reactive flavonoids were identified for A. barbujana, R. maderensis and P. azorica. For R. maderensis a high content $\left(7 \mathrm{mg} \mathrm{g}^{-1}\right.$ dry weight) of L-ascorbic acid, an already described antioxidant phytomolecule, was found. A high content in selenomethionine (414.35 $\mu \mathrm{g} \mathrm{g}^{-1}$ dry weight) was obtained for P. ar borescens subsp. maderensis extract. This selenocompound is already described as a hydroxyl radical scavenger is reported in this work as also possessing peroxyl radical scavenging capacity. This work is a good illustration of different phytomolecules (flavonoids, organic acids and selenocompounds), presents in leaves of the five traditional medicinal plants endemic to Macaronesia, all exhibiting antioxidant properties.

Keywords: antioxidant; L-ascorbic acid; selenomethionine; flavonoid; Macaronesia plants

\section{Introduction}

Oxidative stress represents a disturbance in the equilibrium status of prooxidant/antioxidant reactions in living organisms. The balance between antioxidants and damaging effects of free radicals is a very important aspect and is achieved by mechanisms collectively termed "redox regulation", that protect living organisms from oxidative stresses [1]. The excess of reactive oxygen species (ROS) can damage cellular lipids, proteins or DNA, inhibiting their normal function [2]. Oxidative imbalance has been implicated in a number of human diseases as well as in the ageing process [2]. Therefore the study of ROS and antioxidants in biology triggered a medical revolution that underlies a new age of health and disease management [3]. The continuous upsurge of new challenges ranges from prevention of oxidative reactions in foods to novel pharmaceuticals for treatment/attenuation of chronic degenerative diseases, such as cancer, autoimmune, inflammatory, cardiovascular and neurodegenerative (e.g., Alzheimer's disease, Parkinson's disease, multiple sclerosis, Down's syndrome) diseases, as well as ageing and cosmetics. 
Plant secondary metabolites, such as polyphenols, have been described as exhibiting important antioxidant, antimutagenic, anticarcinogenic, antiinflammatory and antimicrobial effects, that might be potentially beneficial in preventing diseases and contributing to human organism homeostasis.

Flavonoids are the largest group of polyphenols and over 2,000 individual flavonoids have been reported [4]. They are described as antioxidant molecules that scavenge free radicals with their concomitant oxidation and formation of a more stable free radical [5-7]. In recent years, there has been an increasing interest in investigating the various pharmacological properties of flavonoids [8].

The use of traditional medicine is widespread and the plants used constitute a large source of natural antioxidants that might serve as leads for the development of new drugs. The use of traditional herbs and medicinal plants has been traced to the occurrence of natural products and their health improvement capacities. However, other phytomolecules could act as antioxidant defences against ROS. Ascorbic acid (Vitamin C), Vitamin E, glutathione (GSH) and carotenoids are examples of nonenzymatic antioxidant defences [1]. There is also some elements, like $\mathrm{Cu}, \mathrm{Fe}, \mathrm{Mn}$ and $\mathrm{Zn}$, and $\mathrm{Se}$, that occur mostly bound to proteins, forming metalloenzymes that also possess important antioxidant activities. In humans, these trace elements accomplish decisive functions to maintain human health. Deficiency in any of them originates low levels of metalloproteins and/or low enzyme activities, leading to undesirable pathological conditions that may be readily prevented or reversed by adequate supplementation with the missing element.[9]

In this work, five endemic Macaronesian species, from the Azores and Madeira/Canary Islands, belonging to four different families and presenting a recognized ethnobotanical use or belonging to a genus with this sort of use [10-19] were selected (Table 1). Their contents in total phenols (TP) and total flavonoids (TF) were determined. Their antioxidant potential was assessed by measuring the antioxidant capacity for two of the most relevant free radicals for humans: peroxyl and hydroxyl radicals. For a better characterization of antioxidant capacity source, the polyphenolic profile and trace elements were assessed for all species. For $R$. maderensis additional quantification of L-ascorbic acid was performed and in the case of $P$. arborescens subsp. maderensis, free amino acid content was determined. Overall, for each plant under study, an attempt was made to relate their antioxidant capacity with the phytomolecules detected.

Table 1. Folk medicinal uses of $O$. foetens, A. barbujana, R. maderensis, P. arborescens subsp. maderensis and $P$. azorica.

\begin{tabular}{|c|c|c|}
\hline Family & Plant name & Use in folk medicine \\
\hline \multirow{2}{*}{ Lauraceae } & $\begin{array}{l}\text { Ocotea foetens (Ainton) } \\
\text { Baill }\end{array}$ & $\begin{array}{l}\text { O. foetens is used as antihypertensive, treatment for malignant diseases } \\
\text { (poultices) and cancer }[10,11]\end{array}$ \\
\hline & $\begin{array}{l}\text { Apollonias barbujana } \\
\text { (Cav.) Bornm }\end{array}$ & $\begin{array}{l}\text { Plants of this family have been purported in folk medicine as diuretic, } \\
\text { analgesic, antiulcerogenic, cytostatic, cardiotonic, expectorant, stomachic, } \\
\text { sedative or carminative effects and against rheumatic pain [12] }\end{array}$ \\
\hline Polygonaceae & Rumex maderensis Lowe & $\begin{array}{l}\text { R. maderensis infusion is used as a diuretic and blood depurative and } \\
\text { externally applied in poultices for dermatosis }[11,13] \\
\text { Rumex sp. are used to treat headaches, to promote maturation abscess, in } \\
\text { wound healing, for infected wounds and pimples }[14,15]\end{array}$ \\
\hline Plantaginaceae & $\begin{array}{l}\text { Plantago arborescens } \\
\text { Poir. subsp. maderensis } \\
\text { (Decne.) A. Hans. et } \\
\text { Hunk. }\end{array}$ & $\begin{array}{l}\text { Plantago sp. is used in infusion gargled to relieve sore throat, on the } \\
\text { treatment of hepatitis, conjunctivitis, furunculosis, diarrhoea, malignant } \\
\text { diseases, spasm, intestinal and stomach ulcers, stomach ache, tuberculosis, } \\
\text { asthma, cough, bronchitis, boils, diabetes, goiter, it is also used as } \\
\text { hemostatic, antitussive and expectorant and applied externally as a poultice } \\
\text { to treat wounds, cuts and bee bites [10,11,15-19] }\end{array}$ \\
\hline
\end{tabular}


Table 1. Cont.

\begin{tabular}{lll}
\hline & Prunus azorica (Mouill.) & \\
Rosaceae & Rivas Mart., Lousã, & Prunus spp. are used in treatment of urinary tract diseases $[16,18,19]$ \\
& Fern.Prieto, E.Días, & \\
& J.C.Costa \& C.Aguiar & \\
\hline
\end{tabular}

\section{Results and Discussion}

\subsection{Total phenol and flavonoid content}

For each of the Macaronesia plants under study (A.barbujana, O.foetens, P. azorica, P. arborescens subsp. maderensis and $R$. maderensis), three leaf extractions with three clean solvents (water, 1:1 water-ethanol mixture and absolute ethanol) were used to select the best clean solvent for phenolic compound extraction (Figure 1). For all plants, the total content in polyphenols in the waterethanol extract was either higher or not significantly different from the ethanolic extract. Subsequent HPLC analysis revealed that the water-ethanol extract possessed all peaks detected in the three types of extractions but in higher quantities (data not shown). For these reasons, further studies proceeded only for the water-ethanol extracts. A. barbujana presented the highest content in total phenolics in the

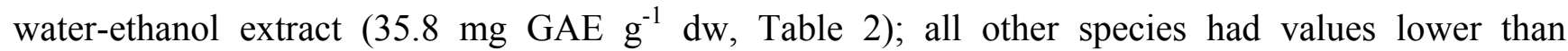
$15.5 \mathrm{mg} \mathrm{GAE} \mathrm{g}^{-1} \mathrm{dw}$.

Figure 1. Total phenol content of the five Macaronesia plants under study. The extracts for the three types of solvents were evaluated for each plant: white bar- water; grey barwater:ethanol (1:1); black bar- ethanol. Vertical bars represent \pm SD. * - significantly different extractions at $\mathrm{p}<0.05$.

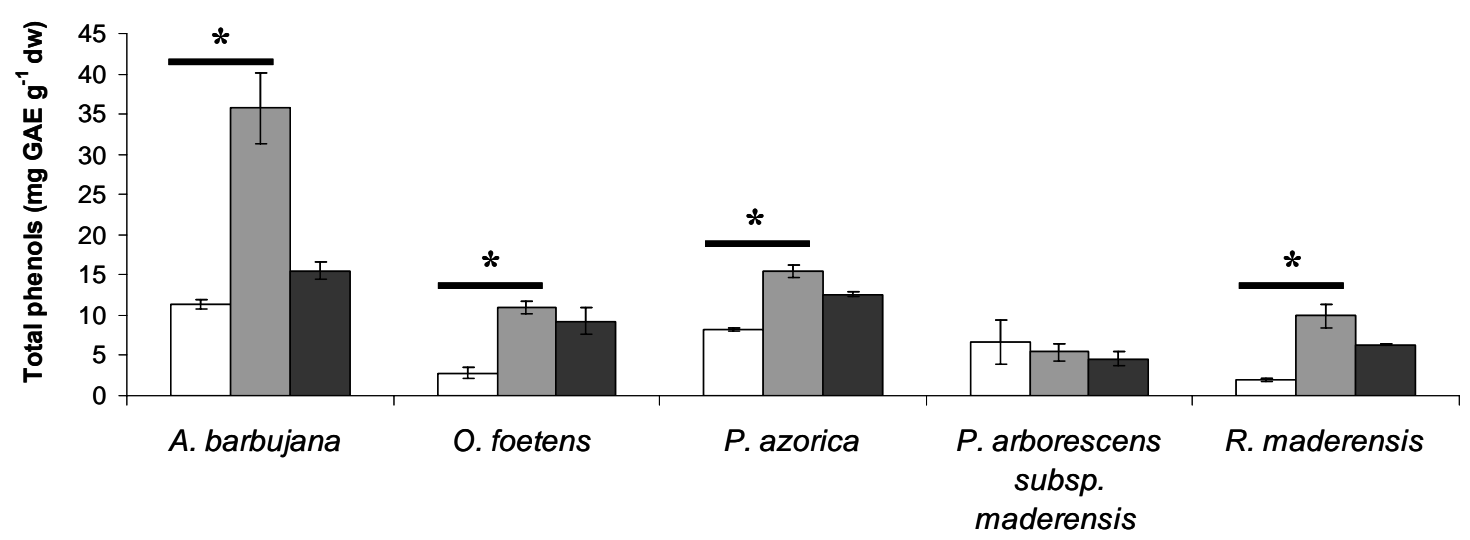

Since flavonoids are strongly associated with antioxidant capacity, the total flavonoid content in these plants was also determined (Table 2) for the water-ethanol extracts of plants studied. In accordance with phenol quantification, A. barbujana was the richest species in flavonoids, followed by P. azorica, O. foetens, R. maderensis and finally by P. arborescens subsp. maderensis. Based on these results, P. azorica had clearly a greater contribution of flavonoids to the total phenol content in contrast with $P$. arborescens subsp. maderensis which had a very low content in TF. There is no data available in the literature related with the phenolic and flavonoid leaf content of these species, despite their folk medicinal use, these plants were until now uncharacterized. 
Table 2. Total phenols (TP) content and total flavonoids (TF) content for the water:ethanol extracts of the five Macaronesia plants under study. Values are the mean of three independent replicates \pm SD. Superscript letters are the significance levels at $\mathrm{p}<0.05$.

\begin{tabular}{|c|c|c|}
\hline Plant species & $\begin{array}{l}\text { Total phenols (TP) } \\
\left(\mathrm{mg} \mathrm{GAE}^{-1} \text { dw) }\right.\end{array}$ & 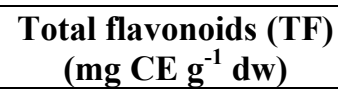 \\
\hline A. barbujana & $35.8 \pm 4.4^{\mathrm{a}}$ & $18.31 \pm 2.51^{\mathrm{a}}$ \\
\hline O. foetens & $10.9 \pm 0.8^{b c}$ & $5.03 \pm 0.42^{\mathrm{c}}$ \\
\hline P. azorica & $15.4 \pm 0.8^{b}$ & $11.29 \pm 0.21^{\mathrm{b}}$ \\
\hline P. arborescens subsp. maderensis & $5.4 \pm 1.1^{\mathrm{c}}$ & $0.22 \pm 0.02^{\mathrm{d}}$ \\
\hline R. maderensis & $9.9 \pm 1.6^{\mathrm{bc}}$ & $5.23 \pm 0.10^{c}$ \\
\hline
\end{tabular}

\subsection{Free radical scavenging activity}

The capacity of plant extracts to scavenge peroxyl (ROO) and hydroxyl $(\cdot \mathrm{OH})$ radicals was measured by the Oxygen Radical Absorbance Capacity (ORAC) method and Electron Paramagnetic Resonance (EPR), respectively (Figures 2 and 3, respectively). These ROS are the two major free radicals with biological relevance in the human body.

Figure 2. Peroxyl radical scavenging activity for the water:ethanol extracts of the five Macaronesia plants under study. Each point is the average of three independent replicates. Values are the mean of three independent replicates and bars represent SD. Superscript letters are the significance levels at $\mathrm{p}<0.05$.

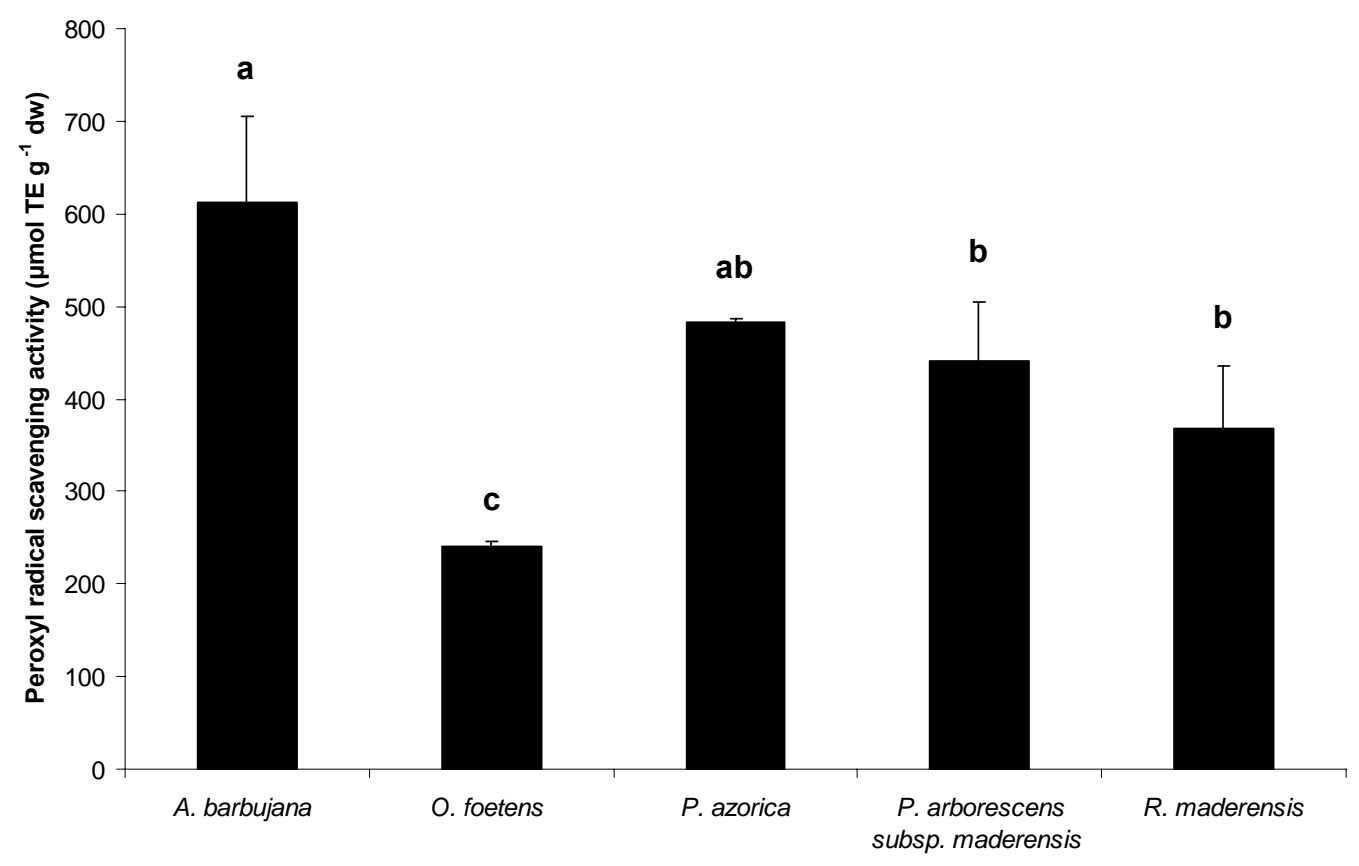


Figure 3. Effect of the water:ethanol extracts of the five Macaronesia plants under study on the EPR spectra, as described in the section 3.5. The percentage represents the relative attenuation of the EPR signal amplitude relative to that of the standard.
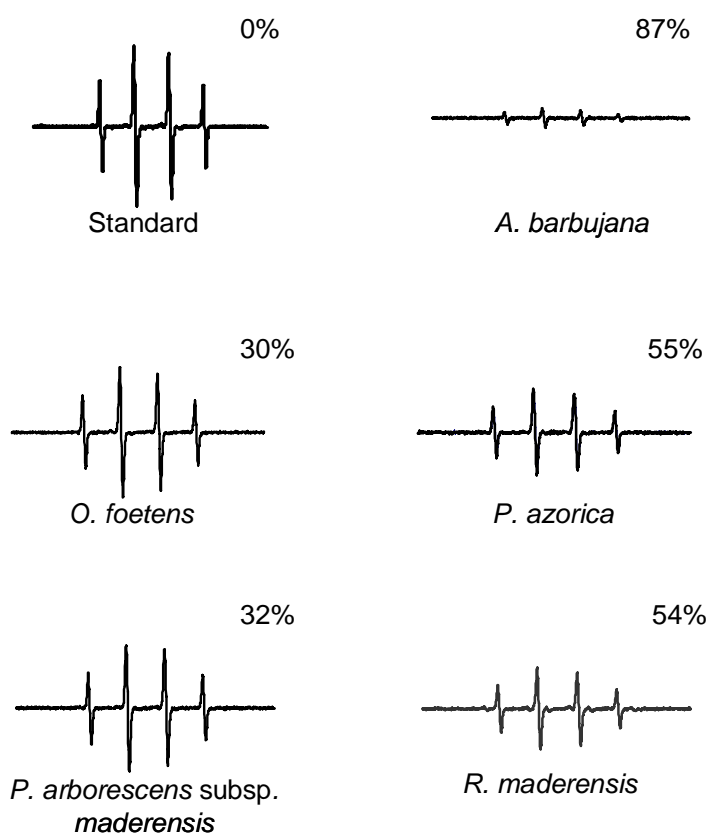

A. barbujana extract was clearly the most potent in scavenging both radicals (Figures 2 and 3 ). In general, in plant extracts there is a positive relationship between TF (Table 2) content and antioxidant capacity, higher content in TF reflects in higher antioxidant capacity. However, some considerations should be discussed for some particular extracts. Concerning peroxyl radical scavenging capacity (Figure 2), it is interesting to consider the similar antioxidant capacity for P. arb orescens subsp. maderensis and P. azorica, since they presented quite different TF content (Table 2). On the other hand, although $R$. maderensis and $O$. foetens presented similar TF content, the former exhibited twice the antioxidant capacity of the latter.

Similar analysis for hydroxyl radical scavenging capacity (Figure 3) led to equivalent conclusions. The magnitude of the difference in antioxidant capacity between $R$. maderensis and O.foetens remained the same (two fold). Curiously, P. azorica's ability to scavenge hydroxyl radical was comparable to that of $R$. maderensis, although the former had a much higher TF content (Table 2). The same pattern is observed for P. arborescens subsp. maderensis and O. foetens - they presented a very different content in flavonoids, but similar hydroxyl radical scavenging capacity.

These results suggest either the existence of flavonoids displaying widely different antioxidant potencies and/or the possible occurrence of compounds interfering in antioxidant capacity and/or the presence of antioxidant molecules other than flavonoids. Previous works have already described the presence of interfering compounds in total extracts that after being removed allowed the enhancement of the extracts' bioactivities [20,21]. To better understand the origin of antioxidant capacity from the leaf extracts of these plants, an additional number of experiments were performed and are discussed below. 


\subsection{HPLC profile}

The compositional analysis of the water-ethanol leaf extracts from the plants under study was evaluated by High Performance Liquid Chromatography with Diode Array Detection and Electrochemical Detection (HPLC-DAD-ED). Peaks detected by the electrochemical detector correspond to reactive species with strong capacity to donate electrons. Therefore, a positive correlation between the total area of peaks detected in the electrochemical chromatogram (Figure 4A) and the antioxidant properties of the extracts (Figure 2 and 3 ) is likely to be found. The sum of the area of the peaks detected in this system for each species is presented in Figure 4A. In this evaluation, $P$. azorica showed the greater total ED peak area, followed by R. maderensis and A. barbujana, with similar total areas; O. foetens and P. arborescens subsp. maderensis produced no significant areas. This evaluation reflects only those compounds that are distinguished by the electrochemical detector and that are involved in redox reactions.

$O$. foetens and P. arborescens subsp. maderensis originated HPLC profiles with several low intensity hardly detectable peaks (data not shown), as expected from their low flavonoid content (Table 2). The resulting chromatograms from the electrochemical detection and the UV spectroscopic detection at $280 \mathrm{~nm}$ are shown in Figures 4B to D for A. barbujana, P. azorica and R. maderensis, respectively.

Figure 4. Phytochemical characterization of the five Macaronesia leaf water-ethanol extracts using the diode array (DAD) at $280 \mathrm{~nm}$ and the electrochemical detectors (ED) in tandem $(-1 \mathrm{~V},+1 \mathrm{~V})$. (A) Total area of the peaks detected electrochemically for the five plant extracts studied; Chromatographic profiles of A. barbuj ana (B); P. azorica (C); $R$. maderensis (D); Chromatograms at $280 \mathrm{~nm}$ and peak identification (E) of A. barbujana (Ab), P. azorica (Pa) and $R$. made rensis $(\mathrm{Rm})$. Peak identification: 1. Ascorbic acid; 2. Gallic acid; 3. Protocatechuic acid; 4. Neochlorogenic acid; 5. Caffeic acid; 6. Procyanidin B2; 7. Hydroxycinamic acid derivate; 8. Epicatechin; 9. Caffeic acid derivate 1; 10. Procyanidin; 11. Coumaric acid; 12. Rutin; 13. Quercetin/ kaempferol/ myrcetin glucosydes; 14. Caffeic acid derivate 2; 15. Apigenin; 16. Naringenin.
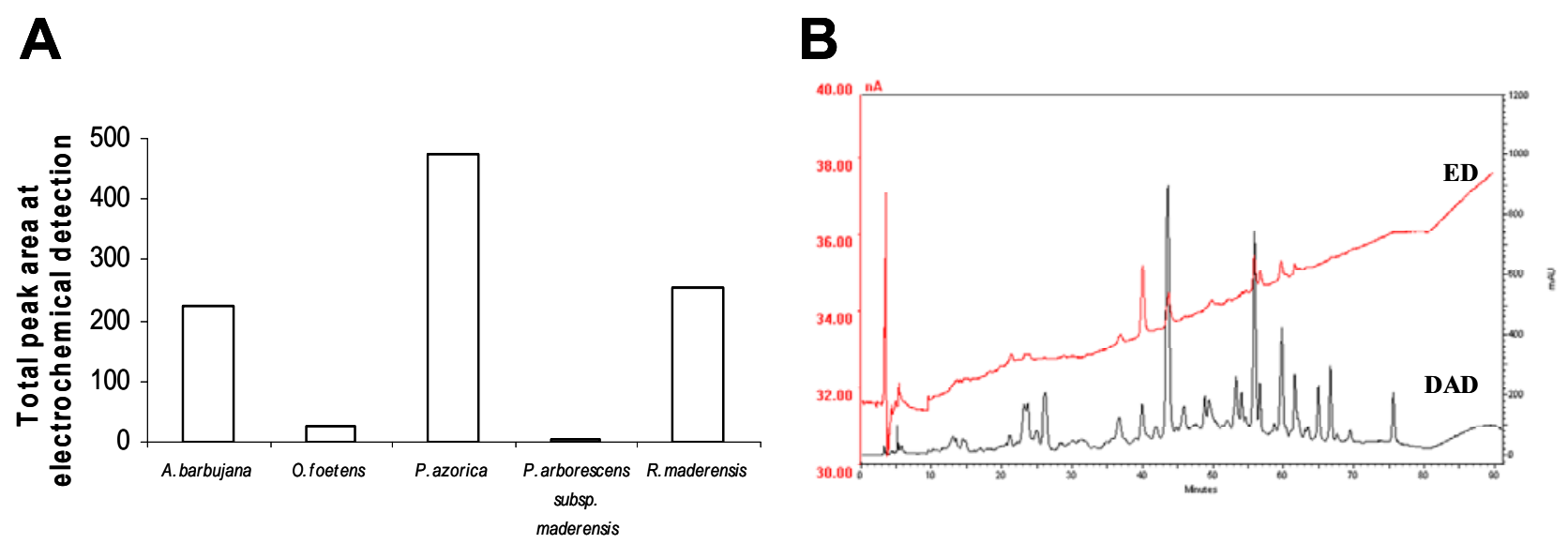
Figure 4. Cont.
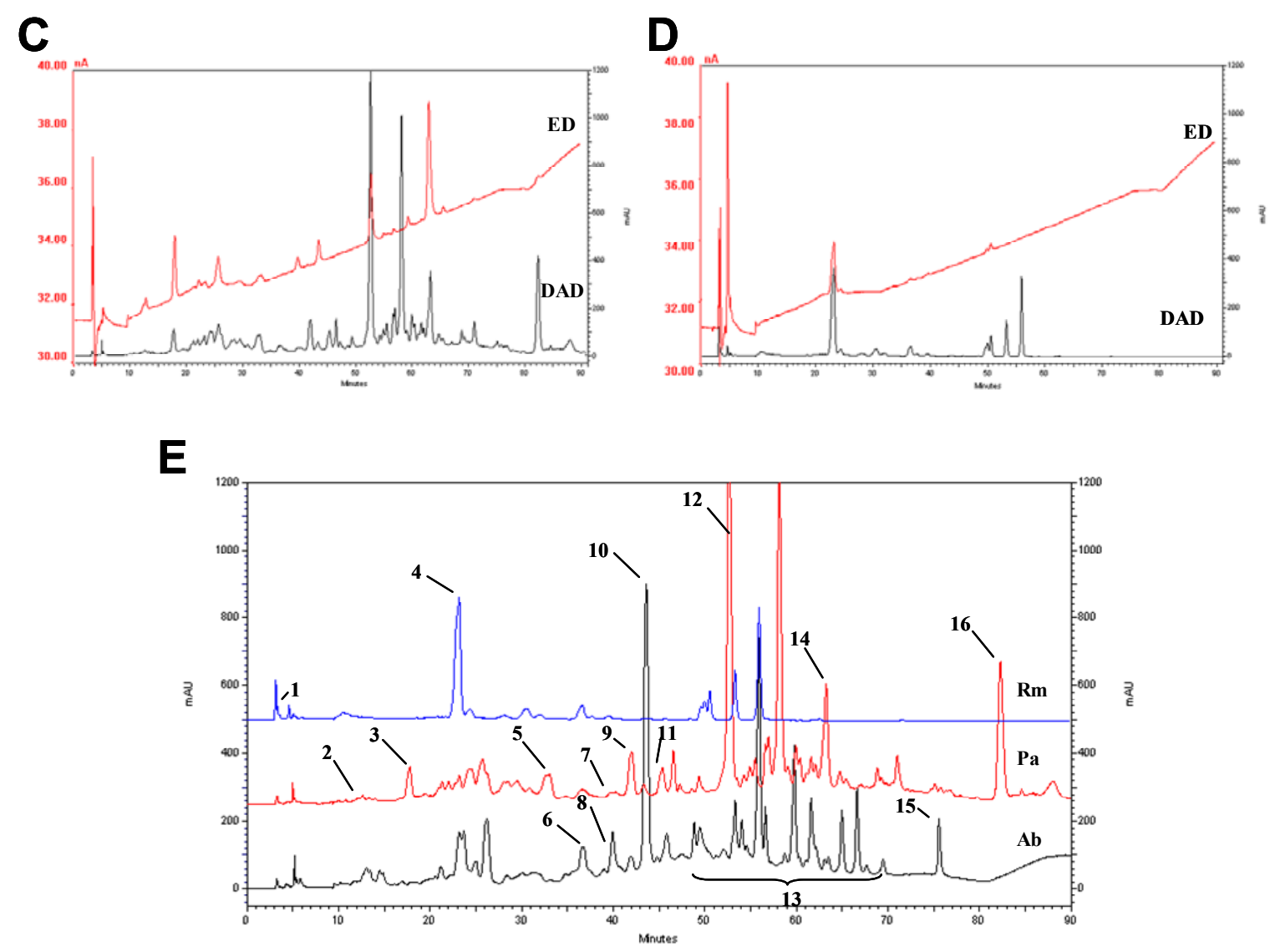

The total peak area obtained employing an electrochemical detector in the electrical detector for $P$. azorica may be explained by its higher content in TF (Table 2). This is in good agreement with the antioxidant properties detected by ORAC (Figure 3a) and EPR (Figure 3b). A. barbujana, that had shown the highest antioxidant potential for both radicals evaluated, had a total peak area from electrochemical detection equivalent to $R$. maderensis. The value plotted for $R$. maderensis in Figure 4A is mainly due to a single peak, as shown in the HPLC-ED profile (Figure 4D), identified as Lascorbic acid (peak number 1, Figure 4E). This compound could contribute to the antioxidant capacities detected by ORAC and EPR [22-24]. The presence of ascorbic acid would explain the variation of the scavenging activity between $O$. foetens (devoid of L-ascorbic acid) and $R$. maderensis. $O$. foetens showed a lower antioxidant capacity than $R$. maderensis, however, both extracts presented similar amounts of polyphenols and/or flavonoids (Figure 3). The presence of L-ascorbic acid in $R$. maderensis was confirmed by an enzymatic method $\left(9.00 \pm 0.60 \mathrm{mg} \mathrm{g}^{-1} \mathrm{dw}\right)$ and validated by an HPLC analytical methodology for organic acids, with the content in this compound determined as $7.0 \pm 1.2 \mathrm{mg} \mathrm{g}^{-1} \mathrm{dw}$.

Tentative identification of the compounds fractionated by HPLC (Figure 4) has been made by examination of their UV spectra and comparison with standards. Each class of flavonoids has a typical UV absorption maxima and the classification proposed by Robards and Antolovich has been used in this work for identification purposes [25]. Flavones typically exhibit an intense band II (310-350 nm) absorption maximum with a shoulder or low intensity peak representing band I (250-280 nm). 
Flavonols absorb at 250-280 nm (band II) and 350-385 $\mathrm{nm}$ (band I), while hydroxycinnamic acids lack band I and exhibit absorption at 227-245 $\mathrm{nm}$ and at 310-332 (band II).

Flavonoids identified in A. barbujana extract (Fig. 4B) that could be associated to its antioxidant capacity due to their redox reactivity (ED signals) were epicatechin, procyanidins and flavonol derivatives. In P. azorica extract (Figure 4C) the main antioxidant molecules were protocatechuic and coumaric acids, caffeic acid derivatives and rutin. In $R$. maderensis leaf extract, neochlorogenic acid was also found as contributing for antioxidant capacity in addition to the ascorbic acid contribution.

\subsection{Trace elements and free amino acids}

The results obtained above for the antioxidant properties of plant extracts suggest the presence of molecules other than polyphenols contributing to radical scavenging activity, this led us to determine selected trace elements contents by ICP (Inductively Coupled Plasma). Metals as $\mathrm{Cu}, \mathrm{Fe}, \mathrm{Mn}$ and $\mathrm{Zn}$, and the non-metal Se, are considered trace elements because of their essentiality and their very limited requirements by humans. The biological activities of $\mathrm{Cu}, \mathrm{Fe}, \mathrm{Mn}$ and Se are strongly associated with the presence of unpaired electrons that allow their participation in redox reactions. Zn has no unpaired electrons but has been recognized to act as an antioxidant by replacing metals that are active in catalyzing free radical reactions [9].

The contents in the trace elements analyzed for $P$. azorica are in accordance with the values reported in the literature for other species of the same genus [26-35] (Table 3). There is no data available in the literature for these elements in plants of the genera Ocotea and Apollonias. Table 3 also shows, for $R$. maderensis, that while $\mathrm{Cu}$ and $\mathrm{Fe}$ contents are lower than the reported values, $\mathrm{Zn}$ content agrees with the literature. There is no information related to $\mathrm{Mn}$ and Se contents.

The discrepancies observed for plant species between the trace element content reported in Table 3, in comparison with values in literature, may be due to species specific differences or to differences in the amount and form in which these elements are available to the plants in the soil [36].

Table 3. Contents in $\mathrm{Cu}, \mathrm{Fe}, \mathrm{Mn}$, Se and $\mathrm{Zn}$ of the five Macaronesia plants under study.

The values reported here from the literature refer to species that belong to the same genus.

\begin{tabular}{|c|c|c|c|c|c|c|c|c|c|c|}
\hline \multirow{2}{*}{$\begin{array}{l}\text { Plant } \\
\text { species }\end{array}$} & \multicolumn{2}{|c|}{$\mathrm{Cu}\left(\mu \mathrm{g} \mathrm{g}{ }^{-1} \mathrm{dw}\right)$} & \multicolumn{2}{|l|}{$\mathrm{Fe}\left(\mu \mathrm{g} \mathrm{g}^{-1} \mathrm{dw}\right)$} & \multicolumn{2}{|c|}{$\operatorname{Mn}\left(\mu g g^{-1} d w\right)$} & \multicolumn{2}{|l|}{$\operatorname{Se}\left(\mu g^{-1} d w\right)$} & \multicolumn{2}{|c|}{$\mathrm{Zn}\left(\mu \mathrm{g} \mathrm{g}^{-1} \mathrm{dw}\right)$} \\
\hline & $\begin{array}{l}\text { Determined } \\
\text { values }\end{array}$ & $\begin{array}{l}\text { Reference } \\
\text { values }\end{array}$ & $\begin{array}{l}\text { Determined } \\
\text { values }\end{array}$ & $\begin{array}{l}\text { Reference } \\
\text { values }\end{array}$ & $\begin{array}{l}\text { Determined } \\
\text { values }\end{array}$ & $\begin{array}{l}\text { Reference } \\
\text { values }\end{array}$ & $\begin{array}{l}\text { Determined } \\
\text { values }\end{array}$ & $\begin{array}{l}\text { Reference } \\
\text { values }\end{array}$ & $\begin{array}{l}\text { Determined } \\
\text { values }\end{array}$ & $\begin{array}{l}\text { Reference } \\
\text { values }\end{array}$ \\
\hline O. foetens & 12.43 & & 34.40 & & 12.34 & & 0.13 & & 14.47 & \\
\hline P. azorica & 6.87 & $4.8-23.8^{\mathrm{a}, \mathrm{b}, \mathrm{g}, \mathrm{h}}$ & 66.81 & $\begin{array}{l}25.18^{-} \\
1117^{\mathrm{h}, \mathrm{i}, \mathrm{j}, \mathrm{k}}\end{array}$ & 16.65 & $\underset{\mathrm{a}, \mathrm{b}, \mathrm{g}, \mathrm{h}}{1.8-74.8}$ & 0.07 & $\begin{array}{l}0.003- \\
0.088^{\mathrm{g}, \mathrm{h}}\end{array}$ & 11.99 & $\underset{\mathrm{a}, \mathrm{b}, \mathrm{g}, \mathrm{h}}{1.8-49.8}$ \\
\hline $\begin{array}{l}P . \\
\text { arborescens } \\
\text { subsp. } \\
\text { maderensis }\end{array}$ & 13.58 & $15.2-41.1^{\mathrm{e}}$ & 160.64 & & 27.17 & $80.5-229^{e}$ & 0.26 & $0.2^{\mathrm{f}}$ & 46.08 & $36.5-71.8^{c}$ \\
\hline $\begin{array}{l}R . \\
\text { maderensis }\end{array}$ & 9.75 & $19-39^{\mathrm{c}, \mathrm{d}}$ & 190.68 & $241-425^{\mathrm{h}}$ & 29.20 & & 0.13 & & 47.71 & $37-120^{\mathrm{c}, \mathrm{d}}$ \\
\hline
\end{tabular}

Legend: a [26]; b [27]; c [28; 29]; d [30]; e [31]; f [32]; g [33]; h [35]; i [34]; j [33]; k [29].

For P. arborescens subsp. maderensis, $\mathrm{Cu}$ and $\mathrm{Mn}$ contents are lower than those already described, while the Se content $\left(0.26 \mu \mathrm{g} \mathrm{g}^{-1} \mathrm{dw}\right)$ is above the expected value for Plantago genus. Plants convert Se mainly into selenomethionine, about $50 \%$ of the total Se content, whereas selenocysteine (Se-Cys), 
methyl-Se-Cys and g-glutamyl-Se-methyl-Cys are not significantly incorporated into plant protein and are at relatively low levels irrespective of soil Se content [37]. Selenomethionine has been described as a potent antioxidant molecule [38-41], on the other hand higher animals are unable to synthesize it and the ingested Se-Met is absorbed in the small intestine by active transport in mammals [37].These evidences make this molecule very interesting antioxidant with biological significance. The presence of high contents in this trace element in the P. arborescens subsp. maderensis extract, may contribute to its antioxidant properties, since this plant contains scarce detectable flavonoids, or other relevant compounds detected by HPLC- DAD (results not shown).

In order to confirm the presence of a biological active antioxidant species, total free amino acid profile of $P$. arborescens subsp. maderensis leaf extract was obtained by HPLC-DAD as described in Section 3.9. The results of the free amino acid quantification, presented in Table 4, illustrate the presence of high selenomethionine and selenocysteine contents in the leaves of $P$. arborescens subsp. maderensis, when compared with other free amino acids.

Table 4. Contents of free amino acids present in the water:ethanol extract of $P$. arborescens subsp. maderensis.

\begin{tabular}{ccc}
\hline Free amino acid & Molecular weight & Content $\left(\boldsymbol{\mu g ~ g}^{-1} \mathbf{~ d w}\right)$ \\
\hline Hydroxyproline & 131.1 & 253.60 \\
Serine & 105.1 & 23.11 \\
Asparagine & 132.1 & 83.35 \\
Proline & 115.4 & 105.40 \\
Se-Cysteine & 182.08 & 122.60 \\
Valine & 117.2 & 152.72 \\
Se-Methionine & 196.11 & 414.35 \\
\hline
\end{tabular}

At concentrations present in P. arborescens subsp. maderensis extract (Table 5), selenomethionine possessed an antioxidant capacity against peroxyl radical equivalent to $12.90 \mathrm{TE}$, while in the same conditions selenocysteine presents $0.63 \mathrm{TE}$. This is the first time that is reported peroxyl radical scavenging capacity exhibited by selenomethione. This compound has already being referred in literature as displaying antioxidant capacity for free radicals such as hydroxyl and peroxynitrite [39-41]. These results point out that selenocompounds, in particular selemomethionine are contributing for the antioxidant capacity of P. arborescens subsp. maderensis leaf extract, practically devoid of flavonoid compounds.

Table 5. Antioxidant capacity of pure selenoamino acids commercial available at the concentrations present in $P$. arborescens subsp. maderensis extract. Values are the mean of three independent replicates $\pm \mathrm{SD}$.

\begin{tabular}{ccc}
\hline Free amino acid & Concentration $\left(\mathrm{mg} \mathrm{mL}^{-1}\right)$ & Peroxyl radical scavenging activity (TE) \\
\hline Se-Cysteine & 0.0024 & $0.63 \pm 0.13$ \\
Se-Methionine & 0.0080 & $12.90 \pm 2.15$ \\
\hline
\end{tabular}

Selenium supplementation has already been described as reinforcing the endogenous antioxidative systems and therefore being beneficial as an adjuvant therapy for some human pathologies. Selemethionine is efficaciously absorbed and retained in animals and presents antioxidant properties 
for biologically significant free radicals, as discussed. In this work P. arborescens subsp. maderensis revealed as an interesting source of this physiologically relevant selenocompound.

\section{Experimental}

\subsection{Plant material}

Leaves from five plants endemic to the Macaronesian islands were collected in December 2006 at the Ajuda Botanical Garden, Lisbon, Portugal, and stored at $-80{ }^{\circ} \mathrm{C}$. The selected plants were Apollonias barbujana (Cav.) Bornm. (LISI 557/2009, M.D. Espírito Santo), Ocotea foetens (Aiton) Baill (LISI 558/2009, M.D. Espírito Santo), Prunus azorica (Mouill.) Rivas-Mart., Lousã, Fern. Prieto, E. Días, J.C. Costa \& C. Aguiar (LISI 562/2009, M.D. Espírito Santo), Rumex maderensis Lowe (LISI 563/2009, M.D. Espírito Santo), and Plantago arborescens Poir. subsp. maderensis (Dcne.) A. Hans. et Kunk. (LISI 559/2009, M.D. Espírito Santo). For all species, voucher samples were authenticated and deposited at the herbarium "João de Carvalho e Vasconcelos", Instituto Superior de Agronomia, Lisbon, Portugal.

\subsection{Extraction procedure}

For each plant species, three different extractions were performed using three clean solvents (water, 1:1 water-ethanol mixture, and absolute ethanol) to select the best clean solvent for the extraction of phenolic compounds. Plant leaves were ground to a fine powder with a grinder. To each $1 \mathrm{~g}$ of powder, solvent $(6 \mathrm{~mL})$ was added and the mixture was shaken for $30 \mathrm{~min}$, at room temperature in the dark. The mixture was then centrifuged at $12,400 \mathrm{~g}$, during $10 \mathrm{~min}$ at room temperature. The supernatant was filtered through paper filter and then through $0.20 \mu \mathrm{m}$ cellulose acetate membrane filters. The resulting extracts were frozen at $-80^{\circ} \mathrm{C}$ under a nitrogen atmosphere and subsequently dried under vacuum to determine the dried extract yield. The yields of dried extracts were $11 \%(\mathrm{w} / \mathrm{w})$ of the starting material for A. barbujana and P. azorica, and 5\% (w/w), 4\% (w/w) and 3\% (w/w) for $O$. foetens, $P$. arborescens subsp. maderensis and $R$. maderensis, respectively.

\subsection{Total phenolic content}

Determination of total phenolic compounds was performed by the Folin-Ciocalteau method [42]. Briefly, to each well of a microplate water $(235 \mu \mathrm{L})$, sample (or solvent, in the control, $5 \mu \mathrm{L}$ ), FolinCiocalteau's reagent $\left(15 \mu \mathrm{L}\right.$, Fluka $\left.{ }^{\circledR}\right)$ and saturated $\mathrm{Na}_{2} \mathrm{CO}_{3}$ aqueous solution $(45 \mu \mathrm{L})$ were added. The microplate was incubated for $30 \mathrm{~min}$ at $40^{\circ} \mathrm{C}$ and the absorbance at $765 \mathrm{~nm}$ measured. Gallic acid was used as the standard and the results are expressed in mg of gallic acid equivalents per gram of dry weight (mg GAE $\mathrm{g}^{-1} \mathrm{dw}$ ) of plant material.

\subsection{Total flavonoid content}

Measurement of flavonoid content was performed by a modification of the $\mathrm{AlCl}_{3}$ complexation method [43]. To each well of a 96-well plate, water $(125 \mu \mathrm{L}$ ), sample (or solvent, in the control, $25 \mu \mathrm{L})$ and $5 \%(\mathrm{w} / \mathrm{v}) \mathrm{NaNO}_{2}(7.5 \mu \mathrm{L})$ were added. The plate was incubated for 6 min at room 
temperature and then $10 \%(\mathrm{w} / \mathrm{v}) \mathrm{AlCl}_{3}(15 \mu \mathrm{L})$ were added. After incubation during 5 min, $1 \mathrm{M} \mathrm{NaOH}$ $(100 \mu \mathrm{L})$ was added and the solution of each well was mixed. The absorbance was measured at $510 \mathrm{~nm}$. (+)-Catechin hydrate, minimum 98\% (w/w) was used as the standard, and the results are expressed as $\mathrm{mg}$ catechin equivalents per gram of dry weight $\left(\mathrm{mg} \mathrm{CE}^{-1} \mathrm{dw}\right)$ of plant material.

\subsection{Free radical scavenging assays}

\subsubsection{Peroxyl radical scavenging capacity}

Peroxyl radical scavenging capacity was determined by the ORAC method [24,44]. Briefly, the reaction mixture contained sodium fluorescein $(1,800 \mu \mathrm{L}, 4 \mathrm{nM}$, Uranine, Fluorescein Sodium Salt@, TCI Europe), sample $(300 \mu \mathrm{L})$ and 2,2'-azobis(2-amidopropane)dihydrochloride (300 $\left.\mu \mathrm{L}, 41.4 \mathrm{~g} \mathrm{~L}^{-1}\right)$. The blank contained $75 \mathrm{mM}$ phosphate buffer ( $\mathrm{pH} 7.4,300 \mu \mathrm{L}$ ) instead of the sample, whereas for the calibration it contained of 5 to $50 \mu \mathrm{M}$ 6-hydroxy-2,5,7,8-tetramethylchroman2-carboxylic acid (Trolox $\left.{ }^{\circledR}, 300 \mu \mathrm{L}\right)$. The decrease of fluorescence was monitored kinetically during $30 \mathrm{~min}$ at $37{ }^{\circ} \mathrm{C}$ (excitation: $493 \mathrm{~nm}$; emission $515 \mathrm{~nm}$ ) on a Varian Eclipse 96 Well spectrofluorimeter. The final results were calculated by the difference of area under the curve of fluorescence's decay between blank and sample and are expressed as $\mu \mathrm{mol}$ Trolox ${ }^{\circledR}$ equivalents per gram of dry weight ( $\left.\mu \mathrm{mol} \mathrm{TE} \mathrm{g}^{-1} \mathrm{dw}\right)$ of plant material.

\subsubsection{Hydroxyl radical scavenging assay}

The ability of the plant extracts to scavenge the hydroxyl radicals in the presence of hydrogen peroxide was evaluated by electron paramagnetic resonance (EPR) with the use of the spin-trapping agent, 5,5-dimethyl-1-pyrroline- $N$-oxide (DMPO), as described previously [45]. All EPR measurements were conducted using a Bruker EMX6/1 spectrometer (Bruker Instruments, Billerica, MA, USA) and a flat cell assembly. The EPR spectrometer settings were: receiver gain, $4.48 \times 10^{-4}$; time constant, $20.48 \mathrm{~s}$; modulation amplitude, $1.0 \mathrm{G}$; scan time, $83 \mathrm{~s}$; and magnetic field, $3450 \pm 100$ $\mathrm{G}$, with an X-band frequency of $9.69 \mathrm{GHz}$.

Reactants were mixed in test tubes, containing a phosphate-buffered solution (pH 7.4) with $10 \mathrm{mM}$ DMPO, $0.4 \mathrm{mM} \mathrm{FeSO}_{4}, 2 \mathrm{mM} \mathrm{H} \mathrm{O}_{2}$ and plant extract $(100 \mu \mathrm{L})$ in a final volume of $500 \mu \mathrm{L}$. The reaction mixture was then transferred into a flat cell and the EPR spectra recorded 3 min after reaction initiation. Experiments were performed at room temperature and under ambient air. The signal intensity of DMPO-OH radical adduct was obtained by double integration and the scavenging activity of the extract was estimated as the percent decrease of the relative intensity of the signal with reference to that of the control (without extract).

\subsection{HPLC profile of phenolic compounds}

HPLC analysis was performed as described earlier [46], with a Thermo Finnigan Surveyor instrument (San Jose, CA, USA) equipped with a diode array detector (Thermo Finnigan-Surveyor,) and an electrochemical detector (Dionex, ED40). Briefly, separations were performed at $35{ }^{\circ} \mathrm{C}$ on a LiChrospher C18 (5 $\mu \mathrm{m}, 250 \mathrm{~mm} \times 4 \mathrm{~mm}$ i.d.) column (Merck) with a guard column of the same type. The samples extracted as described above were injected using a $20 \mu \mathrm{L}$ loop. The separations were 
carried out with a flow rate of $700 \mu \mathrm{L} \mathrm{min}{ }^{-1}$ and the mobile phase consisted of a gradient mixture of eluent A (phosphoric acid, 0.1\%, v/v) and eluent B (phosphoric acid-acetonitrile-water 5:400:595, $\mathrm{v} / \mathrm{v} / \mathrm{v}$ ). The following gradient of eluents was used: $0-15 \mathrm{~min}$ from 0 until $20 \%$ eluent $\mathrm{B} ; 10$ min with 20\% eluent B; 25-70 min, from 20 until 70\% eluent B; 70-75 min, with 70\% eluent B; 75-85 min from 70 until 100\% eluent B; $85-90$ min, with $100 \%$ eluent B.

Diode array detection was performed between 200 and $800 \mathrm{~nm}$. Electrochemical detection was programmed for a linear variation from $-1.0 \mathrm{~V}$ to $1.0 \mathrm{~V}$ in $1.00 \mathrm{~s}$ (detection by integrated voltammetry using a cyclic variation of the potential). The measurements were taken with a $50 \mathrm{~Hz}$ frequency with an analogic/digital converter. The data acquisition systems were the Chromquest version 4.0 (Thermo Finnigan-Surveyor) for the diode array detector and the Unicam 4880 software for the electrochemical detector.

\subsection{Quantification of L-ascorbic acid}

L-Ascorbic acid content in the extract previously prepared was quantified by an enzymatic method, using the kit K-asco from Megazyme, according to the manufacturer instructions. To validate the L-ascorbic acid quantification it was performed a new plant extraction using phosphoric acid $\left(6 \mathrm{~mL} \mathrm{~g}^{-1} \mathrm{fw}\right)$. The homogenate was then centrifuged at $13,000 \mathrm{~g}$ for $20 \mathrm{~min}$ at $4{ }^{\circ} \mathrm{C}$ and the supernatant filtered using $0.20 \mu \mathrm{m}$ cellulose acetate membrane filters. L-Ascorbic acid was determined using an isocratic method with glacial acetic acid $5 \%(\mathrm{v} / \mathrm{v})$ and a flow rate of $1 \mathrm{~mL} \mathrm{~min}{ }^{-1}$. The oven temperature was set to $25^{\circ} \mathrm{C}$, and $20 \mu \mathrm{L}$ sample extract were injected into the Thermo Finnigan HPLC with detection wavelength set at $262 \mathrm{~nm}$. A LiChrospher C18 $(5 \mu \mathrm{m}, 250 \mathrm{~mm} \times 4 \mathrm{~mm}$ i.d. $)$ column (Merck) and a guard column of the same packing material were used. Washing of the column system was performed with $80 \%$ (v/v) acetonitrile and $20 \%$ (v/v) water during $40 \mathrm{~min}$. After washing, column was stabilized with the mobile phase. Standard solutions of L-ascorbic acid prepared in water with concentration values between 10 and $200 \mathrm{mg} \mathrm{L}^{-1}$ were prepared. A linear regression curve was obtained $\left(\mathrm{R}^{2}=0.9995\right)$.

\subsection{Mineral composition}

Plants were collected, washed with water and dried to a constant weight. The samples were then acid-digested with concentrated nitric acid and the minerals determined by Inductively Coupled Plasma-Optical Emission Spectrometry (ICP-OES), except for Se which was determined by Inductively Coupled Plasma- Mass Spectroscopy (ICP-MS; LMI, AB Lennart Mansson International).

\subsection{HPLC quantification of free amino acids}

Extraction was done by adding 12 volumes of $50 \%$ (v/v) ethanol for each gram of dry leaf powder. The samples were stirred for $30 \mathrm{~min}$ and centrifuged (3,500 g, $30 \mathrm{~min})$. The pellets were washed twice with $50 \%(\mathrm{v} / \mathrm{v})$ ethanol. The supernatants were collected, concentrated under vacuum and finally stored at $-20{ }^{\circ} \mathrm{C}$. The free amino acid content of the extracts were analysed on a HPLC (Alliance Waters 2695, with a PDA Detector, 2996) gradient system with precolumn phenyl isothiocyanate (PITC) derivatization of the samples with a NovaPack C18 (4 $\mu \mathrm{m}, 3.9 \mathrm{~mm} \times 300 \mathrm{~mm}$ i.d.) column, as 
described previously [47]. Data acquisition and analysis were made by Empower Software (Waters, Empower Pro, 2002).

\subsection{Statistical analysis}

The results reported in this work are the average of at least three biological replicates and are represented as the mean \pm SD. Differences among treatments were assessed by analysis of variance [48] with Tukey HSD (Honest Significant Difference) multiple comparison test $(\alpha=0.05)$ using SigmaStat 3.10 (Systat).

\section{Conclusions}

The Plant Kingdom represents a wide reservoir of phytocomplexes and natural compounds that still wait for a proper identification and characterization. Among them, many have recognized ethnopharmacological relevance and are "heavy loaded" with bioactive compounds.

The five selected species (A. barbujana, O. foetens, P. azorica, P. arborescens subsp. maderensis and $R$. maderensis), all endemic to Macaronesia, are used in folk medicine to treat diseases in which oxidative stress seems to be involved. Thus, it is crucial to determine not only their antioxidant capacity but also to characterize its origin. For O. foetens, $P$. azorica, and A. barbujana the antioxidant capacity seems to be associated mainly to their flavonoid contents. For $R$. maderensis and $P$. arborescens subsp. maderensis, other phytomolecules than flavonoids, were found to contribute to their antioxidant capacity. Ascorbic acid was related to $R$. maderensis antioxidant capacity, while selenomethionine was related with $P$. arborescens subsp. maderensis antioxidant capacity. This selenocompound, already described with hydroxyl radical scavenging capacity, was also reported in this work as presenting peroxyl radical scavenging capacity. In conclusion, this study shows that chemically distinct groups of compounds (flavonoids, organic acids and selenocompounds) contribute differentially for antioxidant properties of the five medicinal plants endemic to Macaronesia.

\section{Ackowledgements}

The authors wish to thank the Fundação para a Ciência e Tecnologia for financial support of C. Santos (SFRH/BPD/26562/2006), L. Tavares (SFRH/BD/37382/2007) and A. Serra (SFRH/BD/19238/2004). We also want to acknowledge all ethnobotanical informations provided by Amélia Frazão, Ana Maria Carvalho, Félix Rodrigues and Graça Mateus. We would like also to thank the data provided by Analytical Laboratory, Analytical Services Unit, Instituto de Tecnologia Química e Biológica, Universidade Nova de Lisboa.

\section{References}

1. Valko, M.; Leibfritz, D.; Moncol, J.; Cronin, M.T.; Mazur, M.; Telser, J. Free radicals and antioxidants in normal physiological functions and human disease. Int. J. Biochem. Cell Biol. 2007, 39, 44-84.

2. Halliwell, B. Free radicals, antioxidants, and human disease: Curiosity, cause, or consequence? Lancet 1994, 344, 721. 
3. Aruoma, O.I. Methodological considerations for characterizing potential antioxidant actions of bioactive components in plant foods. Mutat. Res. 2003, 523-524, 9-20.

4. Ramassamy, C. Emerging role of polyphenolic compounds in the treatment of neurodegenerative diseases: a review of their intracellular targets. Eur. J. Pharmacol. 2006, 545, 51-64.

5. Cao, G.; Sofic, E.; Prior, R.L. Antioxidant and prooxidant behavior of flavonoids: structureactivity relationships. Free Radic. Biol. Med. 1997, 22, 749-760.

6. Salah, N.; Miller, N.J.; Paganga, G.; Tijburg, L.; Bolwell, G.P.; Riceevans, C. Polyphenolic flavanols as scavengers of aqueous phase radicals and as chain-breaking antioxidants. Arch. Biochem. Biophys. 1995, 322, 339-346.

7. Saija, A.; Scalese, M.; Lanza, M.; Marzullo, D.; Bonina, F.; Castelli, F. Flavonoids as antioxidant agents: importance of their interaction with biomembranes. Free Radic. Biol. Med. 1995, 19, 481-486.

8. Esposito, E.; Rotilio, D.; Di Matteo, V.; Di Giulio, C.; Cacchio, M.; Algeri, S. A review of specific dietary antioxidants and the effects on biochemical mechanisms related to neurodegenerative processes. Neurobiol. Aging 2002, 23, 719-735.

9. Fraga, C.G. Relevance, essentiality and toxicity of trace elements in human health. Mol. Aspects Med. 2005, 26, 235-244.

10. Branco, A.F. A flora madeirense na medicina popular. Separata da Revista "Brotéria" 1935, IV, $35-46$.

11. Rivera, D.; Obon, C. The ethnopharmacology of Madeira and Porto-Santo islands, a review. $J$. Ethnopharmacol. 1995, 46, 73-93.

12. Perez, C.; Trujillo, J.M.; Almonacid, L.N.; Navarro, E.; Alonso, S.J. New C 13 -norisoprenoids from Apollonias barbujana. Nat. Prod. Lett. 1996, 8, 1-6.

13. Ballabio, R. Plantes médicinales endémiques de l'île de Madère. Phytothérapie 2004, 2, 41-46.

14. Kupeli, E.; Orhan, I.; Yesilada, E. Evaluation of some plants used in Turkish folk medicine for their anti-inflammatory and antinociceptive activities. Pharm. Biol. 2007, 45, 547-555.

15. Guarrera, P.M.; Forti, G.; Marignoli, S. Ethnobotanical and ethnomedicinal uses of plants in the district of Acquapendente (Latium, Central Italy). J. Ethnopharmacol. 2005, 96, 429-444.

16. Santos, S.; Correia, A.I.D.; Figueiredo, A.C.; Dias, L.S.; Dias, A.S. Plantas medicinais da península de Setúbal. Contribuição para o conhecimento da sua relevância etnobotânica. In Potencialidades e aplicações das plantas arom áticas e medicinais. Curso teórico-prático;

Figueiredo, A.C., Barroso, J.G., Pedro, L.G., Eds.; Faculdade de Ciências da Faculdade de Ciências da Universidade de Lisboa - Centro de Biotecnologia Vegetal: Lisboa, Portugal, 2007; pp. 175-182.

17. Sequeira, M.M.; Fontinha, S.M.G.S.V.; Freitas, F.I.C.; Ramos, L.C.; Mateus, M.G.H. Plantas e usos tradicionais nas memórias de hoje ; Casa do Povo da Ilha/ Parque Natural da Madeira: Funchal, Portugal, 2006.

18. World Health Organization. WHO Monographs on Select ed Medicinal Plants ; WHO: Geneva, Switzerland, 1999.

19. World Health Organization. WHO Monographs on Select ed Medicinal Plants ; WHO: Geneva, Switzerland, 2007. 
20. Tavares, L.; Fortalezas, S.; Carrilho, D.; McDougall, G.J.; Stewart, D.; Ferreira, R.B.; Santos, C. Antioxidant and antiproliferative properties of strawberry tree tissues. J. Berr y Res. 2010, Accepted.

21. Seeram, N.P.; Adams, L.S.; Hardy, M.L.; Heber, D. Total cranberry extract versus its phytochemical constituents: Antiproliferative and synergistic effects against human tumor cell lines. J. Agric. Food Chem. 2004, 52, 2512-2517.

22. Ou, B.; Hampsch-Woodill, M.; Flanagan, J.; Deemer, E.K.; Prior, R.L.; Huang, D.J. Novel fluorometric assay for hydroxyl radical prevention capacity using fluorescein as the probe. $J$. Agric. Food Chem. 2002, 50, 2772-2777.

23. Atala, E.; Vásquez, L.; Speisky, H.; Lissi, E.; López-Alarcón, C. Ascorbic acid contribution to ORAC values in berry extracts: An evaluation by the ORAC-pyrogallol red methodology. Food Chem. 2009, 113, 331-335.

24. Cao, G.; Alessio, H.M.; Cutler, R.G. Oxygen-radical absorbance capacity assay for antioxidants. Free Radic. Biol. Med. 1993, 14, 303-311.

25. Robards, K.; Antolovich, M. Analytical chemistry of fruit bioflavonoids - A review. Analyst 1997, 122, R11-R34.

26. Ozcan, M. Mineral contents of some plants used as condiments in Turkey. Food Chem. 2004, 84, 437-440.

27. Jimenez, S.; Pinochet, J.; Gogorcena, Y.; Betran, J.A.; Moreno, M.A. Influence of different vigour cherry rootstocks on leaves and shoots mineral composition. Sci. Hortic. 2007, 112, 73-79.

28. Alfawaz, M.A. Chemical composition of hummayd (Rumex vesicarius) grown in Saudi Arabia. $J$. Food Comp. Anal. 2006, 19, 552-555.

29. Shun-xing, L.; Nan-sheng, D.; Feng-ying, Z. Effect of digestive site acidity and compatibility on the species, lipopily and bioavailability of iron, manganese and zinc in Prunus persica Batsch and Carthamus tinctorus. Bioorg. Med. Chem. Lett. 2004, 14, 505-510.

30. Del Rio, M.; Font, R.; Almela, C.; Velez, D.; Montoro, R.; Bailon, A.D. Heavy metals and arsenic uptake by wild vegetation in the Guadiamar river area after the toxic spill of the Aznalcollar mine. J. Biotechnol. 2002, 98, 125-137.

31. Lazaro, J.D.; Kidd, P.S.; Martinez, C.M. A phytogeochernical study of the Tras-os-Montes region (NE Portugal): Possible species for plant-based soil rernediation technologies. Sci. Total Environ. 2006, 354, 265-277.

32. von Boberfeld, W. Effect of selenium containing multi-nutrient fertilizer on selenium and sulphur concentrations depending on main species, growth, and dosage. PflanzenbauwissenschaftenGerman J. Agron. 2002, 6, 84-92.

33. Calisir, S.; Haciseferogullari, H.; Ozcan, M.; Arslan, D. Some nutritional and technological properties of wild plum (Prunus spp.) fruits in Turkey. J. Food Eng. 2005, 66, 233-237.

34. Zarrouk, O.; Gogorcena, Y.; Gomez-Aparisi, J.; Betran, J.A.; Moreno, M.A. Influence of almond $\mathrm{x}$ peach hybrids rootstocks on flower and leaf mineral concentration, yield and vigour of two peach cultivars. Sci. Hortic. 2005, 106, 502-514.

35. Moodley, R.; Kindness, A.; Jonnalagadda, S.B. Elemental composition and chemical characteristics of five edible nuts (almond, Brazil, pecan, macadamia and walnut) consumed in Southern Africa. J. Environ. Sci. Health B 2007, 42, 585-591. 
36. Finley, J.W. Selenium accumulation in plant foods. Nutr. Rev. 2005, 63, 196-202.

37. Tapiero, H.; Townsend, D.M.; Tew, K.D. The antioxidant role of selenium and selenocompounds. Biomed. Pharmacother. 2003, 57, 134-144.

38. Rayman, M.P. The importance of selenium to human health. Lancet 2000, 356, 233-241.

39. Assmann, A.; Bonifacic, M.; Briviba, K.; Sies, H.; Asmus, K.-D. One-electron reduction of selenomethionine oxide. Free Radical. Res. 2000, 32, 371-376.

40. Padmaja, S.; Squadrito, G.L.; Lemercier, J.N.; Cueto, R.; Pryor, W.A. Rapid oxidation of selenomethionine by peroxynitrite. Free Radic. Biol. Med. 1996, 21, 317-322.

41. Priyadarsini, K.I.; Mishra, B. Radical cations of some water-soluble organoselenium compounds: Insights from pulse radiolysis studies. Radiat. Phys. Chem. 2008, 77, 1294-1299.

42. Singleton, V.L.; Rossi, J.A. Colorimetry of total phenolics with phosphomolybdicphosphotungstic acid reagents. Am. J. Enol. Vitic. 1965, 16, 144-158.

43. Michalska, A.; Ceglinska, A.; Zielinski, H. Bioactive compounds in rye flours with different extraction rates. Eur. Food Res. Technol. 2007, 225, 545-551.

44. Wang, S.Y.; Lin, H.S. Antioxidant activity in fruits and leaves of blackberry, raspberry, and strawberry varies with cultivar and developmental stage. J. Agric. Food Che m. 2000, 48, 140-146.

45. Leonard, S.S.; Xia, C.; Jiang, B.H.; Stinefelt, B.; Klandorf, H.; Harris, G.K.; Shi, X. Resveratrol scavenges reactive oxygen species and effects radical-induced cellular responses. Biochem. Biophys. Res. Commun. 2003, 309, 1017-1026.

46. Bravo, M.N.; Silva, S.; Coelho, A.V.; Boas, L.V.; Bronze, M.R. Analysis of phenolic compounds in Muscatel wines produced in Portugal. Anal. Chem. Acta 2006, 563, 84-92.

47. Cohen, S.A.; Bidlingmeyer, B.A.; Tarvin, T.L. PITC derivatives in amino acid analysis. Nature 1986, 320, 769-770.

48. Popova, M.; Bankova, V.; Butovska, D.; Petkov, V.; Nikolova-Damyanova, B.; Sabatini, A.G.; Marcazzan, G.L.; Bogdanov, S. Validated methods for the quantification of biologically active constituents of poplar-type propolis. Phytochem. Anal. 2004, 15, 235-240.

Sample Availability: Samples of the compounds are available from the authors.

(C) 2010 by the authors; licensee Molecular Diversity Preservation International, Basel, Switzerland. This article is an open-access article distributed under the terms and conditions of the Creative Commons Attribution license (http://creativecommons.org/licenses/by/3.0/). 